\title{
Re-reading Ruqyah: Comprehensive Analysis of Ruqyah within Hadith, Medicine, and Psychological Perspective
}

\author{
M. Iqbal Syauqi Al Ghiffary ${ }^{1}$, Ahmad Azwar Habibi ${ }^{2}$, Sayid Ridho ${ }^{3}$, \\ Dini Permana Sari ${ }^{4}$, Ahmad Ubaydi Hasbillah ${ }^{5}$, Sobri Al Majid ${ }^{6}$, \\ Zaitunah Subhan ${ }^{7}$, Hamka Hasan ${ }^{8}$ \\ \{miqbal.syauqi75@mhs.uinjkt.ac.id ${ }^{1}$, ahmad.habibi@uinjkt.ac.id² ${ }^{2}$, sayid.ridho@uinjkt.ac.id ${ }^{3}$, \\ dini_permana18@mhs_uinjkt.ac.id ${ }^{4}$, ubaydihasbillah@ptiq.ac.id ${ }^{5}$, sobri_al18@mhs.uinjkt.ac.id ${ }^{6}$, \\ zaitunahsubchan@uinjkt.acid ${ }^{7}$, hamka.hasan@uinjkt.ac.id $\left.{ }^{8}\right\}$ \\ Faculty of Medicine of Sy arif Hiday atullah State Islamic University, Jakarta, Indonesia ${ }^{13}$ \\ Darus Sunnah International Institute for Hadith Sciences, Jakarta, Indonesia ${ }^{2}$ \\ Graduate School of Sy arif Hiday atullah State Islamic University, Jakarta ${ }^{4678}$ \\ Perguruan Tinggi Ilmu Al-Qur'an
}

\begin{abstract}
Prophetic Medicine is the total authentic Hadith and the tradition of the Prophet Muhammad about medicine. It includes diet manners, natural remedies, and management of illness. In addition to this tradition, the Prophet also taught spiritual treatment containing Qur'anic verses and some prayers which must be read when the sick person comes. There are contradictions between hadith which contains ruqyah theme. One is prohibited, and another was permitted. This article determined ruqyah based on hadith understanding in three perspectives: takhrij, narration analysis, and fiqh al-hadith. This article also describes how far it is applied in modern medical practice. From takhrij with the thematical approach, the popularity of ruqyah practice in the Prophet's life was accepted. It was be prohibited by Prophet in recent age because it may contain shirk, but in a later era, ruqyah was permitted. From narrations analy sis, concluded the main aspect of ruqyah is to revive spirituality through asking protection from God, and ruqyah may be applied in various methods. From fiqh al-hadith analyze that ruqyah is allowed by using the Arabic language, or other words in other languages that are understood by the client and may not contains shirk. In modern medical practice, ruqyah may apply as a supporting matter for diagnostic and therapy process comfortably, in the medical science and psychological perspective. It concludes that ruqyah practice is recommended based on hadith, but its manner, words, or pray, may be practiced in various ways and can be applied as part of modern medical practice and psychotherapy.
\end{abstract}

Keywords: ruqyah; hadith; medical science; psychotherapy.

\section{Introduction}

Medicine has been well known since the past when people in civilization knew the disease. Medicine is the art of restoring lost health from the body. Avicenna mentions that medicine is divided into two objects: speculative drugs, or called theoretical parts, and practical or applied medicine. So he comments that although medicine is based on pure science, it has a speculative and practical aspect. Avicenna shared medical science from his background as a famous philosopher. [1] 
Medicine among Arab society is related to their interaction with other cultures. In the ancient era and some faiths, health definition is related to morality and holiness, so the disease is assumed based on sin, spirit possession, magic, and others. [2]

As a part of a medicinal tradition worldwide, Islamic medicine's definition can vary depending upon the perspective, which can be historical, cultural, scientific, pharmacological, and others. Medicine was mentioned in the Quran only for the beneficial effects of some natural foods, also just bring the guiding spirit that every Muslim has to follow in curing their selves. [3]

As a collection of prophetic words and traditions, many scholars compiled the hadith in many books, mainly in canonical hadith books. Ruqyah is mainly understood as one of the curative matters which the prophet uses. It was much mentioned in many canonical books, especially in the two most widely used and the soundest $\{S\{a h i>h a l B u k h a>r i>$ and $S\{a h i>h$ Muslim. Ruqyah is described as some pray to asking protection to eradicate diseases such as toxic and epilepsy. [4] Ruqyah is used to cure evil's eye (marad\{al 'ayn), snakebite, and in other narration, scorpion and another insect bite well as psychiatric disorders.

There are many contradictions between hadith which contains ruqyah theme. One is prohibited, and another was permitted. Furthermore, Ibn Qutayba writes about ruqyah contradicts human sense. Ibn Qutayba used a collective method to solve it. [5]

In Indonesia, ruqyah is widely used with the Quranic verses, and some pray which are taught by Prophet in hadith. In some communities, there are also used some prays from past Muslim scholars from many books. [6] But noted that ruqyah according to Indonesian people is also constructed by media, such as magazines and films. Some research tells that ruqyah is used as a religious proselytizing, as far as orthodoxy views.

Ruqyah is an ancient therapy that is noted that no effect at all nowadays, despite the religiousness and also spirituality is had therapeutically or at least, significant to support the therapy [7] A treatment based on religious orthodoxy must be analyzed further, and how the universal value of it can be applied in today's world. [8]

This research will analyze the ruqyah hadith collections thematically. Hence, this research will map the dissemination and application of ruqyah, so will be discussed its contains in sanad and matn. So broadly ruqyah application will criticize, in Islamic legal, its manner, and its universal value in medical practice.

\section{Methods}

\subsection{Study Methods}

To extract the hadith thematically (mawdlu' $i$ ) Mahmud T\{\{ahhan methodology towards thematic extraction (takhrij mawdlu'i) of hadith will be used. [9] First, to investigate hadith on the specific theme, Miftah Kunu>zal Sunnahas an index book used to investigate riwayat that contains Prophet permission towards ruqyah. [10]

Secondly, from the extracted hadith, other transmission and narration will be investigated too as muta>bi' from that hadith. As shawa>hid, other companions' transmission which al Tirmidhi cited in his Sunan will be used for it. The extracted hadith transmission will be structured and analyzed (i'tibar), to determine the common link and the transmitter's dissemination, then the difference for every isnad will be identified. [11] To get a clear view of 
ruqyah application, this research will refer to narration about ruqyah applications in Miftah Kunu>zal-Sunnah and the shawahidthat Imam al Tirmidhi cited in his Sunan. [11]

To comprehend the understanding of the hadith, the paper develops within fiqh al-hadith [12] approach regarding the understanding of scholars' commentaries and reviews about ruqyah. The data which is collected will be presented in narrative form and some with some tables which contain a deep analytical description. Thus, the paper is a kind of qualitative research based on literature and suitable research.

This methodology applying a thematical approach.[13] According to al-Zayyan, there are three types of research design of al-hadith al-mawdu'iy. First, thematic research - examining and focusing hadith collections related to the topics or themes from canonical books of hadi>th. Second, thematic research which examines the related hadith of the topics and themes, based on certain books of hadith; third, thematic research design that is depending on the various collection of narration of hadith, related to the particular topic's research.

\subsection{Previous Studies}

Ibn al Qayyim is one who codified hadith and scholars commentaries about medication, ruqyah was also included. Ibn al Qayyim's compile the hadith begins with is sues which be the title of a chapter, so offer some hadith that suitable for the chapter and tell other therapies that popular in his era. [14]

Many research tells us about the contribution of religiousness and spirituality to health, especially in the mental aspect. [15] Some views in interactions between religiosity and healthiness are reviewed in some conclusions. The fact that Islam is a multidimensional religion, unique in its way (based on Arabic culture, especially) and Islam shares common elements with other religions, must be admitted. [7]

The contradiction of ruqyah traditions was compiled by Ibn Qutayba and also al Ha>zimi. There are pursuing to use comparison (muqa>rana al riwayat) and combination (al jam'u) methods. In some narration was cited that Prophet prohibits ruqyah, and on the other side, was permitted it. Toward this problem, Ibn al Qayyim noted that al jam'u methods can be applied. $[5]$

\subsection{Limitation}

In transmission analysis, this research will be limited to Anas bin Malik transmission. First, hadith about rukhsah fi ruqyah mostly transmitted by Anas bin Malik. Second, to get a complete understanding of that theme, Anas bin Malik transmission toward ruqyah is cited in Sunan al Tirmidhi, with the other narration from various transmissions in wa fil bab explanation. Refer to Al Muba>rakfuri, this term is defined as "other hadith that can be included in that chapter properly", which was classified by Imam al Tirmidhi>. [16] Al Tirmidhi>writes that other hadith that proper in theme ruqyah permission in addition to Anas bin Malik transmission, is narrated from Buraydah, 'Imra>n ibn Hus \{ain, Ja>bir ibn Abdillah, A<isha, T\{alq ibn 'Ali>, 'Amr ibn Hazm, and Abi Khuza>mah from his father. [17]

\section{Takhrij Al-Hadith (Hadith Extraction)}

\subsection{Discussion of Anas ibn Malik's Transmission about Ruqyah}


Mahmud T\{ahhan mentioned that some varying methods can be used for hadith extraction. In this research, the concept that will be used is hadith extraction by its specific themes. [9] As noted by Hamza 'Abd Allah al Malibari, one of takhrij's objective is to identify the isnad to know to define the transmission around its similarity, difference, and also to identify the transmitter. [18]

From thematically takhrij al-hadith by using Miftah Kunuz al-Sunnah index book, the results gained as below:

Transmission in Al Muwat $\}$ t $\}$ a 'authored by Imam Ma>lik ibn Anas (w. 179 H), at Kitab at $\mathrm{T}\{\mathrm{ib}$, narrated from Humayd ibn Qays al Makki, [19] narration in al Muwat $\} \mathrm{t}\} \mathrm{a}$ ' narrated from 'Urwa ibn al Zubayr (d. $94 \mathrm{H}$ ) in mursal, Narration in Musnad Ahmad ibn Hanbal, narrated from companions Anas bin Malik (d. $94 \mathrm{H})$ from Waki' ibn Al Jarra>h al Ruasi and Yahya ibn Adam, then Hadith in Musnad Ahmad ibn Hanbal, narrated from 'A<isha binti Abu Bakr (d. 57 H). [20]

This research will be limited to Anas ibn Ma>lik's transmission for some reason. First, because of many hadith containing ruqyah permission theme, mostly was narrated by Anas ibn Ma>lik. Second, to get a thematical understanding from that narration, another transmission will be extracted by using Miftah Kunuz al Sunnahindex book and Nuzhatul Albab fi Qauli al Tirmidhi wa fi al bab to access shawahid. ${ }^{1}$

${ }^{1}$ Hadith analyzed as described below: Abdullah ibn Muhammad ibn Abi Shayba.Musaannaf Ibn Abi Shayba. (Riyadh - Maktaba al Rusyd, 1409 H) Vol. 5 p. 43.; Tama>m ibn Muhammad al Bajali> al Ra>zi>. Al Fawaid. (Riyadh: Maktabah Al Rushd, 1412 H) Vol. 373 p. 1.; Al Husayn ibn Mahmud al Bag\}awi. Sharh al Sunnah. (Damascus: Al Maktab Al Islami, 1983). Vol.12 p. 162.; Abd Rahman al Nasa'i. Sunan al Kubra>. (Beirut: Muassasah al Risa>lah, 2001). Vol. 7 p. 74.; Muslim ibn Hajjaj al Nay sabu>ri>. S\{ahi>h Muslim. (Beirut: Dar Ihy a al Turath al Arabi, 1991) Vol. 4 p. 1725.; Abdullah ibn Muhammad ibn Abi Shaybah.Musaannaf Ibn Abi Shaiba. Vol. 5 p.43.; Muhammad ibn 'Isa al Tirmidhi. Sunan al Tirmidhi>. (Beirut: Dar al Gharb al Islami, 1998). Vol. 3 p. 462.; Ahmad ibn Al-Husain AlBayhaqi, Al Sunan Al-Kubrâ. (India: Majlis Dairah AlMa'arif Al Nizhamiyah, 1344 H). Vol. 9 p. 585 .; Abu Bakr ibn Amr Al Bazzar. Musnad Al Bazzar. (Madina: Maktaba al Ulum wa al Hikam, 2009). Vol. 13 p. 525.; Abu Bakr Muhammad ibn Ja'far al Kharaiti. Makarim al Akhlaq. (Cairo: Dar al Afaq al Arabiya, 1999) Vol. 1 p. 345.; Ahmad ibn Hanbal, Musnad Ahmad ibn Hanbal. Vol. 19 p. 212.; Ahmad ibn Hanbal, Musnad Ahmad ibn Hanbal. Vol. 19 p. 230.; Muhammad ibn Hibba>n al Tamimi. Sahih ibn Hibban. (Beirut: Muassasah al Risalah, 1998) Vol. 13 p. 467.; Abu Nu'aym al Asbihani. Al T\}ib al Nabawi. (Cairo: Dar Ibn Hazm, 2006). Vol. 2 p. 499.; Muhammad ibn Isa al Tirmidhi. Sunan al Tirmidhi. Vol: 3 p. 461.; Muhammad ibn Yazid Abû Abdillah Al-Qazwin. Sunan Ibnu Mâjah. (Beirut: Dar Ihya al Kotob al Arabiy ya) Vol.2 p. 1162.; Abu Bakr Muhammad ibn Ja'far al Kharaiti Makarim al Akhlaq. Vol. 344 p. 1.; Muslim ibn Al-Hajjaj, Słahi>h Muslim. Vol. 4 p. 1725.; Muslim ibn Al-Hajjaj, S\}ahi>h Muslim. Vol. 4 p. 1725.; Muhammad ibn Isa al Tirmidhi. Sunan al Tirmidhi. Vol: 3 p. 461.; As a mutabi' the hadith described as below: Muhammad ibn Ismail Al-Bukhari.Shah>h AlBukha>ri. (Riyadh: Dar Thuq An-Najah, 1422 H) Vol. 7 p. 128Abu Bakr ibn Amr Al Bazzar. Musnad al Bazza>r. Vol. 13 p. 43. Al Bazza>r noted that this narration narrated from 'Abbad ibn Mansur only.; Abu Bakr ibn Amr Al Bazzar. Musnad al Bazza>r. Vol. 14 p. 43. Al Bazza>r comments that the transmission from al'Abbas ibn Dhurayh is difference, because Al Bazzar noted that this narration is from Sha' bi> from Ja $>$ bir and also narrated from Sha'bi $>$ from 'Imran ibn Husayn.; 'dam yarqa' : Al 'Azhim Abadi $>$ commented it as 'inqat\}a'a ba'da jirya>nihi' or stoppage or damage in blood circulation. Look 'Awn al Ma'bud. (Beirut: Dar al Kutub al Ilmiy yah) Vol. 10 p. 271. He also cited Al Sindi's commentary about ruqyah effectivity, that ruqyah causes circulation stoppage as a process of cure.; Abû Dawud Sulaiman ibn Al-Asy'ath.Sunan Abu> Da>wud. (Beirut: Al Maktabah al Asriy y ah, 2009) Vol. 4 p. 11.; Sulayman ibn Ahmad al Tabrani. Mu'jam al Kabir al Tabrani. (Cairo: Maktabah Ibn Taymia, 1994)Vol. 1 p. 254.; 
Mutabi' from hadith of ruqyah permission from Anas ibn Malik narrated from Amir ibn Shurahbil and Abu Qilabah Abdullah ibn Zayd. We can concluded from this analysis that ruqyah permission is a popular hadith, and its quality is authentic (sahih), and its varying and bit difference narration in the many books is allowed and may not affects its qualities. From takhrij and i'tibar, we can be explained as below: (1) Hadith that tells about Prophetic ruqyah permission in Anas ibn Malik transmission mostly was narrated by Yusuf ibn Abd Allah al Harith. (2) As $\} \mathrm{im}$ al Ahwal as a common link (mada $>r k u l l i>$ ) to narration about permission in ruqyah. (3) All of the transmission from Hasan ibn Abi $>\mathrm{S}\{\mathrm{a}>$ lih, Sufya $>n$ al Thawri, Yazid ibn $\mathrm{Ha}>\mathrm{ru}>\mathrm{n}$, dan Abu> Khaithamah is narrated from 'As \}im al Ahwal. (4) As an As \}im al Ahwal's student, Sufya $>n$ al Thawri is being a partial common link (mada>r far' $i>$ ), has a much more transmitter than others. (5) Transmission from Hasan ibn Abi S \}alih, Yazi>d ibn Harun, and Abu Khaithamah is a single strand. (6) Al Tirmidhi stated that transmission from Yahya ibn $\mathrm{A}<\mathrm{dam}$ is more authentic than Muawiyah ibn Hisham's transmission. [17]

The transmission above noted some differences in narration. The narration may less in some content, flipped in narration each other, and may use different words. But we can determine that the differences do not impact the quality of the hadith, because it may be permis sible.

Notably that because its popularity and the hadith was assessed by many scholars, like al Tirmidhi and Muslim that some transmission above is sound hadith. Assessment of hadith as a sound hadith may assist the other hadith's quality about ruqyah practice, also because of its popularity too.

\subsection{Narration about Ruqyah in Prophetic Traditions}

Hadith that was extracted here comprising ruqyah application from hadith extraction using Miftah Kunuz al-Sunnah index. Takhrij was limited to six books of hadith because of its privilege in the wider Muslim community.

This research concludes that ruqyah is a popular therapy in that age, according to many narrations from the varying transmission that said ruqyah was used in their community. Because we will determine ruqyah values in biomedicine as a conventional and popular therapy worldwide, this note will analyze the report from hadith about the symptom, therapy methods, and its effect.

From extraction and analysis toward hadith ${ }^{2}$ of ruqyah application, some points found: (1) Prophet had prohibited ruqyah application, worrying about being mixed with shirk. But later

Sulayman ibn Ahmad al Tabrani. 1994. Mu'jam al Kabir al Tabrani. Vol. 1 p. 254.; Al-Hakim AnNaisaburi. Al-Mustadrak 'ala Al-Sahi>hain. (Beirut: Dar Al Ma'rifah, 2002) Vol. 4 p. 458

${ }^{2}$ Hadith extracted and analyzed as below: Ahmad ibn Hanbal, Musnad Al-Imam Ahmad ibn Hanbal. Bab musnad Jabir ibn Abdilla. Vol 22 p. 279; Muslim ibn Al-Hajjaj.Shahîh Muslim. Bab Istihbab al Ruqyah min al 'Ayn wa al humah. Vol. 4 p. 1726; Ahmad ibn Al-Husain Al-Bayhaqi>.As-Sunan Al-Kubrâ.Vol. 9 p. 591; Abu Bakr ibn Abi Shaybah. Musannaf Ibn Abi Shayba. Vol. 5. p. 42.; Ahmad ibn Hanbal.Musnad Al-Imam Ahmad ibn Hanbal. Vol. 39 p. 464.; Sulayman ibn Ahmad al Tabrani. Mu'jam al Kabir al Tabrani. Vol. 8 p. 333.; Muhammad ibn Hibban al Tamimi. Sahih ibn Hibban.. Vol. 13 p. 460.; Ahmad ibn Hanbal, Musnad Al-Imam Ahmad ibn Hanbal.Musnad 'Amr ibn Hazm al Ansari. Vol 39 p. $477 . ;$ Muhammad ibn Yazid Abû Abdillah Al-Qazwin., Sunan Ibnu Mâjah.Bab ruqyah al hayyah wa al 'aqrab. Vol. 2 p. 1163.; Muhammad ibn Isa al Tirmidhi. Sunan al Tirmidhi. Bab Ma Ja'a fi al ruqa wa al adwiya. Vol. 4 p. 399.; Abu Bakr Muhammad ibn Ja'far al Kharaiti. Makarim al Akhlaq . Bab al ruqa wa al 'awdh. Vol. 1 p. 352.; Muslim ibn Al-Hajjaj.Sahih Muslim. Vol.4 p. 1727.; Muslim ibn Al-Hajjaj, Sahih Muslim. Vol. 4 p. 1726.; Muhammad ibn Isa al Tirmidhi. Sunan al Tirmidhi. Vol. 3 p. 460.; Abu Nu'aym al Asbihani. Al Tib al Nabawi. Vol. 2 p. 497.; Muslim ibn Al-Hajjaj, Sahih Muslim. Vol. 4 p. 
1728.; Ahmad ibn Hanbal.Musnad Al-Imam Ahmad ibn Hanbal. Vol. 14 p. 464.; Muslim ibn Al-Hajjaj. Sahih Muslim. Vol.4 p. 1728.; Muhammad ibn Yazid Abû Abdillah Al-Qazwin., Sunan Ibnu Mâjah. Vol. 2 p. 1164.; Muhammad ibn Ismail Al-Bukhari. Sahih Al-Bukhari. Vol. 7 p.132.; Muslim ibn AlHajjaj.Shahih Muslim. Vol. 4 p. 1726.; Abû Dawud Sulaiman ibn Al-Asy'ath. Sunan Abû Dawud, Vol. 4 p. 12.; Abd Rahman al Nasa'i. Sunan al Kubra. Vol. 7 p. 73.; Muhammad ibn Yazid Abû Abdillah AlQazwin., Sunan Ibnu Mâjah.. Vol. 2 p. 1162.; Muhammad ibn Ismail Al-Bukhari. Shahîh Al-Bukhâri. Bab al Mar'ah tarqi al rajul. Vol. 7 p. 134.; Abd Rahman al Nasa'i. Sunan al Kubra. Al Nafth fi al ruqyah. Vol 7 p. 77.; Muhammad ibn Yazid Abû Abdillah Al-Qazwini.Sunan Ibnu Mâjah.Bab al Nafts fi al ruqyah. Vol 2 p. 1166.; Muhammad ibn Hibban al Tamimi. Sahih ibn Hibban. Bab qiraatu Aisha al mu'awwidhatayn 'ala al Mustafa. Vol. 14 p. 555.; Muslim ibn Al-Hajjaj, Shahîh Muslim. Vol. 4 p. 1729.; Sulayman ibn Dawud. Musnad Abi Dawud al Tayalisi. Masruq 'an Aisha. (Egypt: Dar Hajar, 1999) Vol. 3 p. 31 ; Abdullah ibn Muhammad ibn Abi Syaibah, Musaannaf Ibn Abi Shayba. Bab Ma Ja'a fi Thawab 'Iyadah al Marid. Vol 2 p. 444.; Muslim ibn Al-Hajjaj, Shahîh Muslim. Vol. 4 p. 1726.; Ahmad ibn Hanbal.Musnad Al-Imam Ahmad ibn Hanbal.Vol 41 p. 422.; Muhammad ibn Isa al Tirmidhi. Sunan al Tirmidhi. Bab Ma> fi> Du'a> al Marid\}. Vol. 5 p. 561.; Abd Rahman al Nasa'i. Sunan al Kubra. Kitab 'Amal al Yaum wa Lailah. Vol 9 p. 372.; Ahmad ibn Al-Husayn Al-Bayhaqi>.As-Sunan Al-Kubrâ. Bab wad'u al yad 'ala al maridl. Vol 3 p. 535.; Muslim ibn Al-Hajjaj, Shahîh Muslim. Bab Istihbab al ruqyah min al 'ayn wa al humah. Vol 4 p. 1724.; Abd Rahman al Nasa'i. 2001. Sunan al Kubra. Kitab al Nikah, Bab al bikr yuzawwijuha abuha. Vol 5 p. 176.; Abu Nu'aym al Asbihani. Al Tib al Nabawi Bab fi al Quba' Vol. 2 p. 501.; Al-Hakim An-Naisaburi.Al-Mustadrak 'ala As-Sahihayn. Kitab al Ruqa wa al Tamaim. Vol. 4 p. 457.; Al Husayn ibn Mahmud al Bagawi. Sharh al Sunnah. Ma $y a q u>l$ al 'a>id li al mari>dl. Vol. 5 p. 225.; Muslim ibn Al-Hajjaj.Sahih Muslim. Bab Istihbab al ruqyah min al 'ayn wa al humah. Vol 4 p. 1723.; Muslim ibn Al-Hajjaj, Shahîh Muslim. Bab Istihbab al ruqyah min al 'ayn wa al ruqyah. Vol. 4 p. 1726.; Sulayman ibn Ahmad al Tabrani. Mu'jam al Kabir al Tabrani.Bab Atha' ibn Abi Rabah 'an Asma'. Vol. 24 p. 124.; Abd Rahman al Nasa'i. Sunan al Kubra. Bab Ibaha al ruqyah bi kitab Allah. Vol. 9 p. 586.; Muslim ibn Al-Hajjaj, Shahîh Muslim. Bab Istihbab al ruqyah min al 'ayn wa al ruqyah. Vol. 4 p. 1725.; Ahmad ibn Al-Husain Al-Bayhaqi>, As-Sunan AlKubrâ. Ibahat al ruqyah bi kitab Allah. Vol. 9 p. 584.; Abû Dawud Sulaiman ibn Al-Asy'ath.Sunan Ab̂̂ Dawud. Bab fi Ta'liq al Tamaim. Vol. 4 p. 9.; Ahmad ibn Al-Husayn Al-Bayhaqi>, As-Sunan AlKubra>. Bab al Tamaim. Vol. 9 p. 588.; Abû Dawud Sulaiman ibn Al-Asy'ath, Sunan Abu> Dawud. Bab kayf al ruqa. Vol. 4 p. 13.; Abû Dawud Sulaiman ibn Al-Asy'ats, Sunan Abû Dawud. Bab ma jaa fi ruqa. Vol. 4 p. 12.; Muslim ibn Al-Hajjaj, Shahîh Muslim. Bab Laa ba'sa bi al ruqa ma lam yakun fihi shirk. Vol. 4 p. 1727.; Muhammad ibn Hibban al Tamimi. Sahih ibn Hibban. Bab Dhikr Ibahat Istirqa' al mar'u li 'ilal allati tahdith. Vol. 13 p. 462.; Al-Hakim An-Naisaburi, Al-Mustadrak 'ala AshShahîhain. Vol. 4 p. 236.; Ahmad ibn Al-Husain Al-Bayhaqi>, As-Sunan Al-Kubrâ. Ibahat al ruqyah bi kitab Allah. Vol. 9 p. 584.; Abû Dawud Sulaiman ibn Al-Asy'ats, Sunan Abû Dawud. Bab maa jaa fi al ruqa. Vol. 4 p. 11.; Ahmad ibn Hanbal, Musnad Al-Imam Ahmad ibn Hanbal.Hadith sahl ibn hunayf. Vol. 25 p. 351.; Abd Rahman al Nasa'i. Sunan al Kubra. Ma yaqra'u 'ala man usiba bi 'ayn. Vol. 9 p. 380.; Sulayman ibn Ahmad al Tabrani. Mu'jam al Kabir al Tabrani. Al Rabab 'an Sahl ibn Hunayf. Vol. 6 p. 93.; Al-Hakim An-Naisaburi.Al-Mustadrak 'ala As-Sahîhain. Kitab al ruqa wa al tamaim. Vol. 4 p. 458.; Abû Dawud Sulaiman ibn Al-Asy'ath, Sunan Abû Dawud. Bab kayf al ruqa. Vol. 4 p. 13.; Abdullah ibn Muhammad ibn Abi Syaibah. Musaannaf Ibn Abi Shayba.Fi al maridl ma yarqi bihi wa ma yuawwidhu bihi Vol. 5 p. 48.; Muhammad ibn Yazid Abû Abdillah Al-Qazwini, Sunan Ibnu Mâjah.Bab ma 'uwwidha bih al Nabi. Vol. 2 p. 1163.; Muhammad ibn Ismail Al-Bukhari, Shahîh Al-Bukhâri. Bab gazwat khaybar. Vol. 5 p. 133.; Abu Bakr Muhammad ibn Harun al Rawyani.Musnad al Rawyani. (Cairo: Muasasah Qurtubah, 1416 H) Vol. 2 p. 248.; Abû Dawud Sulaiman ibn Al-Asy'ath, Sunan Ab̂̂ Dawud. Bab kayf al ruqa. Vol. 4 p. 12.; Abû Dawud Sulaiman ibn Al-Asy'ath, Sunan Abû Dawud. Bab kayf al ruqa. Vol. 4 p. 13.; Ahmad ibn Hanbal, Musnad Al-Imam Ahmad ibn Hanbal.Vol. 36 p. 155.; Abû Dawud Sulaiman ibn Al-Asy'ath.Sunan Abu Dawud. Bab kayf al ruqa. Vol. 4 p. 13.; Ahmad ibn Hanbal.Musnad Al-Imam Ahmad ibn Hanbal.BabAnas ibn Malik. Vol. 19 p. 85.; Muhammad ibn Isa al Tirmidhi. Sunan al Tirmidhi. Kitab a Tib. Bab. Vol. 4 p. 405.; Abu Bakr ibn Amr Al Bazzar. Musnad Al 
he permitted it. (2) Symptom, compliance, and causal toward an indication of ruqyah in hadith are snake bites, scorpion stings, mental disorder, and evil's eye. (3) Most ruqyah application is using certain prays, or using certain Quranic verses, especially Al-Fa>tihah, Al-Ikhla>s dan Al-mu'awwidhatain. (4) Also, to pray for ruqyah, it may practice by blowing, and also by using water which recited pray on it, saliva spitting, and also with a wipe over the sick area. (5) Permitted to give wages to incantatory. Furthermore, Jews that incapacitate companions show permission of ruqyah practiced by non-Muslim.

There are some conclusions from the analysis of ruqyah application: first, the main aspect in ruqyah is recited adhkar or prays that contain goodness. Second, ruqyah was applied to many people in various methods. Third, as a popular therapy, ruqyah reported can relieve patient compliance in past. Fourth, an indication of ruqyah application is related to animal bites, which can affect physically or mentally.

Some difficulties were found in this analysis. All of the compliance or symptom may be translated to 'sick' or 'illness'. The therapy effect, mentioned words as bari'a, sakana, or shafa, which can be misunderstood is the patient healing, just recovered, or just relieve his symptom? The context in the matn periods is can be analyzed further.

\section{Fiqh Al-Hadith}

Fiqh al-Hadith, refer to Yusni Amru, including takhrij, language discourse, study of Quranic verses, biography of the transmitter, $a s b a>b$ al wuru>d, hadith contradiction, $n a>s i k h$ and mansu $>k h$, and scholars commentaries. [12]

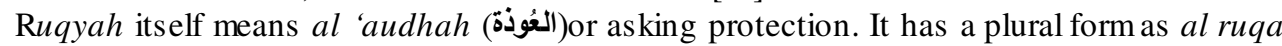
(الرقى). As Ibn Manz\}ur cited from Ibn al Athir, ruqyah is prayed and ask for protection from illnesses like fever, epilepsy, or convulsions. [21]

Ruqyah, in Western terminologies, is using the term incantation or magical spell. Oxford Dictionary defined magic as the power of apparently influencing events by using mysterious or supernatural forces. [22] Medical therapy with a spell was widely used not only in East culture but also in European culture, especially before the Enlightenment era which came in about the $16^{\text {th }}$ century. [23] Ibn Qutayba explains the hadith in which Prophet was being spelled by Jews. Ibn Qutayba said that those who do not agree with ruqyah, contradict with mostly culture in the world, like did Hindus, Christian, Rome, and also Arabs. [5] Al Quran also said that Muslims can ask for protection, for example by reciting surah al Falaq.

Some verses are widely used as a reason for ruqyah permis sion. In surah Al Isra: 82, Allah said:

We send down (stage by stage) in the Qur'an that which is a healing, and a mercy to those who believe; to the unjust it causes nothing but loss after loss. (QS. A1 Isra: 82).

Al Jaza>iri>, notes that the meaning of 'ma> huwa shifa>' is Allah send down the Qur'an that may cure the stupidity, misguided, hesitant and bad prejudice, also it would be a mercy to whom believe because they do the God's revelation and His order. The preposition 'min'(من) is understood by Al Jaza>iri it has bayaniyah function - so Quran as healing and mercy for who believe is the Al-Quran itself entirely, not it is as basis or supplementation. [24] Al Tantawi also cited that (من) preposition word in this verse has means min al jinsiyah. So Al

Bazzar. Musnad ibn Abbas. Vol. 11 p. 94.; Muhammad ibn Yazid Abû Abdillah Al-Qazwin., Sunan Ibnu Mâjah.Bab ma yu'awwidhu min al huma. Vol. 2 p. 1165. 
Qur'an entirely, if it recited and practiced comprehensively in life, Al Qur'an would become a healer and mercy for those who believe. [25]

Quraish Shihab comments about Quranic verses as healing, he cited Hasan Al Basri>commentaries that Al Quran is a revelation not to cure physical illness, but to improve and enhance human spirituality. Function as shifa >' above is not for physical problems, but for the spirit that may be impacted to the body. [26]

Imam al Sha $><$ fii presented that ruqyah is permitted if the words saying by the incantatory (raaqi) contain from Al Quran verses or Arabic words that contain Allah's name, or words known in its meaning which not contradicted with Al Quran and prophetic tradition. [27] If ruqyah is practiced by other words from Arabic words, it will be worried contains words that indicate to shirk.

Ibn al Qayyim in al Tib al Nabawi writes that the incantation being practiced must abide by the following rules. First, the recited incantation must follow the ruqyah condition and permissible in Islam. Second, acknowledgment of the spell and recitation is understandable and does not contain any form of worshipping that leads to shirk if it is a non-Arabic language or native local language. Third, the practitioner is not a shaman, sorcerer, or fortune teller and all the other black magic practitioners. The practitioner must have a good personality and is religious. Fourth, incantation techniques and implementation. This is referring to the technique practiced by shaman and sorcerer using charms and amulets, an incantation that includes offering, incantation recitation in dirty places. [14]

Sahal Mahfudh wrote about ruqyah practice, especially in the Javanese tradition, which is called suwuk. As a living tradition, Sahal noted that suwuk may allow if no shirk in its manner and content, and local language is allowed to be used. [28]

\section{Discussion About Ruqyah Practice}

Prophetic medicine is popular amongst the Muslims because its doctrinal and theological contents were considered by most Muslimhistorians and physicians in the early Islamic era. In its true context, Islamic medicine can be defined as a body of medical knowledge that was inherited by the Muslims in the early phase of Islamic periods, from many sources, which all is be translated to Arabic, but also expounded and assimilated to being Islamicized. [3]

Ibn Khaldu>n, said that the Bedouins in their culture, have a kind of medicine which they based primarily on experience restricted to a few patients only, and which they have inherited from their tribal leaders. In some cases it is correct, but it is not founded on natural laws, nor is it tested against scientific methods and the natural constitution of peoples. [29]

In the later periods, traditional medication especially based on the mystical approach, in spite is still practiced, was not popularly taught and assessed as far as the biomedical approach on medication. The existence of traditional medication practice are related to people's acceptance of the tradition, and also religious views.

The role of spirituality and religion in sickness and health has gained ascendancy in recent years, with some suggesting that it has become part of the biopsychosocial model. Some evidence suggests that strong religious beliefs, prayer, and rituality have positive influences on a person's mental and physical health. [30] Healthcare providers need to be aware of spirituality in their patients' lives and sensitive to their patients' religious beliefs. Despite, according to Abu Raiya systematic review about Islamic ritualism or many methods to cure 
diseases, especially mental diseases, it is so being problematic. [7] Therefore, we will clarify the practice of ruqyah from the perspective of medical science and psychology

\subsection{Ruqyah Practices in the Perspective of Psychology}

The practice of ruqyah is marked by dhikr or prayer, saying words of praise (ta'awudz), forgiveness (istigfar), or recitation of the Holy Qur'an, which repeatedly by opening meetings about God (the transcendental) and hoping for healing their disease or suffering. From a psychological perspective, the practice of medicine or ruqyah therapy can be understood in a variety of psychology concepts of self-healing, [31] religious and-or spiritual healing [32], [33], and meditation [34], [35], [36]. In general, this concept uses transpersonal, which emphasizes spirituality and religion in humanistic psychotherapy. This therapy is based on philosophical questions that are asked on personal questions related to the meaning and purpose of one's life. [37] In psychology, the practice of ruqyah, spiritual healing or meditation, develops according to the flow of Transpersonal Psychology, which focuses on forms of human consciousness. [38]

Ruqyah, in the psychological of communication perspective, shows the characteristics of self-healing, because it has related to intrapersonal communication, where the process of processing information in a person that starts with sensation (the process of digging up information), perception (the process of finding meaning to become new information), memory (the process saving new information and recall that information) and think (process and manipulate the information to meet their needs/healing). [39] In the process of communication in a person, there is a dialogue that supports or gets access to their heart that has been closed by him. [40] In Ruqyah, presenting God, and the hope of healing shows two characteristics in spiritual healing. [41] Ruqyah practices is a training process to develop the internal or inner world to increase the meaning of life, that's mean called meditation. [38]

Ruqyah in the perspective of Islamic psychotherapy is practically exemplified by the angel Gabriel who reveres the Messenger of Allah by understanding: "In the name of Allah I am blessing you from everything hurt and everything related or with spiteful glasses. Allah is the one who healed you. In the name of Allah, I will bless you (HR Muslim no. 2186; Sunan Tirmidzi no. 894; Sunan Ibnu Majah no. 3514, 3515, 3518, Musnad Ahmad no. 9381, 10793, 11046). Based on this hadith, the ruqyah is efficacious for the treatment of various diseases, including malice which is heart disease. To say the name of Allah and consider Him to be a dhikr. [42] Dhikr is a part of Islamic psychotherapy, specifically included in the worship psychotherapy model. [43]

Dhikr also works to appease (thuma'ninah) the heart (Q.S. al-Ra'd: 28), to produce good fortune (falah) (Q.S. al-Anfal: 45), where the people who do the dhikr will be supported by angels, enveloped in the mercy of Allah, returned (sakinah), also called Allah from those on His side (Sunan Tirmidzi no. 3300). Apart from thuma'ninah, sakinah also places Allah in the hearts of believers (Q.S. al-fath: 4). In the realm of Islamic psychotherapy, the heart is the center of human health and the manifestation of the elements of the human body, in which conditions aql, nafs, and spirit can use the heart. [44] This is by the words of the Prophet: if the condition of Qalb is good then all the condition of the body is good, and if it is damaged then the whole body is damaged (Sunan Darimi no. 2419; Shahih Ibnu Hibban no. 297).

Ruqyah is broadly a therapy by reciting good prayers from the Al-Qur'an and as-Sunnah for healing disease. [45] Al-Quran is a better medicine (ad-dawa) (HR Ibnu Majah), and as a 
healer (ash-shifa) and a mercy to the mu'min and not wrongdoers (dzolim) (Q.S. al-Isra: 82). AlQurthubi explains about as-syifa's decision is related to two things, first, to restore the heart from the disease of ignorance and doubt; second, as a healer of physical ailments using ruqyah, taawudz, and its kind. [46]

Ruqyah interpretation and ruqyah practice have gained support as evidenced by research, approved by Gunawan, et al (2017) [36] and Rafique, et al (2017) [47] proving about the reading of QS. al-Rahman can reduce depression in one's heart as a form of ash-shifa from Allah. Also, studies and various empirical research discuss the practice of ruqyah (its mean reading of the Al-Qur'an, meditation of dzikir or ruqyah syar'iyyah, self-healing, spiritual healing) can reduce anxiety [48], [49], [50], [51], depression [52], [53], [50], [54], stress [55], psychosomatic [56], and hysteria behavior. [57] Ruqyah practice can also improve one's calmness [58], spiritual quality [54], and happiness [59], [60], [61], as a characteristic of an individual's mental health. Ruqyah practices are an effort to restore human nature (fitroh) that has inner peace and happiness.

\subsection{Ruqyah Practices in the Perspective of Medical Science}

From a modern medical treatment perspective, Ruqyah was widely examined in various ways and can be put as a part of coping with religious treatment. It can be used simultaneously with the main treatment if the disease is caused by nonphysical for example as depression or mental illness treatment [53]. As a secondary treatment, ruqyah can be used on chronic diseases, for supporting treatment such as cancer patients, which often has a tremendous impact on a patient's quality of life. It is also associated with the experience of uncertainty, vulnerability, hopelessness, fear, depression, anger, and anxiety of a lifetime - which may make mental therapy-related disorder, either physically based or mentally based more difficult [62].

Different from the western medical perspective, in ancient Islamic medical history, doctors in Islam always put a coping religious-like Ruqyah as a part of treatment. They practiced holistic and comprehensive treatment for the patient. As a tradition, Ruqyah according to Rohmansyah et.al was covered some aspects: authority and legal (shari'a) aspect, manner aspect, faith aspect, effectivity and efficacy aspect, and so economic aspect. [63] Islam is a multidimensional religion; Islam might mean different things to different people, and some people might adhere to some of its elements but not to others.

There are some notes that Islamic rituals look similar to other religions and faith, like in prayer or fasting. Ruqyah as spiritual therapy, is maybe useful to moslem only, or in wider concept, can apply to other faith or not? On the contrary, how means a pray from other faith is delivered to moslem, refer to the last chapter, ruqyah by other faith is permitted by the Prophet.

Islam's role in the lives of Muslims seems mostly positive and on the other side, some types of Islamic religiousness are negative. Most studies conducted among Muslims provide only a bird-eye view of Islam and the majority of research in this field has been restricted to convenient samples. The samples used in the study about the impact of religiosity in treatment were used in a limited sample. Particular conditions of the study subjects to be considered. Also, further research is needed on the effects of prayer and religiosity on Muslim personalities. Despite the negative attitude of official Islam, magic practices have over the centuries become intricately interwoven with religious elements and practices. [23]

We can conclude that The Prophet suggests reciting a certain prayer to maintain health, as the Prophet also practiced to treat someone. Some hadith from some companions recorded that 
in past, ruqyah did have an impact on him. As a method that Prophet was taught, 'Qur'anic treatment' has nowadays become highly fashionable even among the elite, as can be seen for instance in some country in the Middle East, where even modern doctors have started to include it in their therapy, recognizing its psychological benefits for many of their patients. The patient's confidence in the divine word, emphasis on talking about the patient's troubles, and the repetition of simple rituals were some factors that may affect.

Ruqyah can be practiced as self-protection, at least to give a more comfortable condition to receive therapy or after therapy. So we can conclude that ruqyah is the reading of prayers or good words as a part of therapy, which can be practiced by all religions and faith. The important thing is not what is pronounced, but what the patient believes. So the current ruqyah is closely related to the patient's spirituality, which is related to the dependability of the servant to his God.

\section{Conclusion}

This research concludes that popular ruqyah practice nowadays is based on narration textual understanding, which uses certain pray and Quranic verses. But when ruqyah is understood as a method and values, it is a method to revive spirituality to support diagnosis or therapy. In other words, "ruqyah practice is recommended based on hadith, but its manner, words, or pray, may be practiced in various ways, and can be applied as a part of in modern medical practice and psychotherapy." Ruqyah is a popular therapy method based on tradition and religious orthodoxies. The Prophet's permission toward ruqyah was supported by many transmissions that narrated it. This research examined Anas ibn Malik transmission. Mutabi and shawahid of the hadith support its legitimacy toward Is lamic legal and practical popularity in past. The core values of ruqyah are prayed to ask for protection from God. This prays, based on the analysis, can practice by all humankind, even by other religion s or faith. Based on narration, ruqyah may not be used as a single or main therapy, but it is used to reviving the spirituality of patients by their religion to feel comfort in the diagnostic or therapy process. Moslem healthcare unit may apply this core of ruqyah, to make good interaction in health empowerment.

\section{References}

[1] Ibn Si>na>, Husayn ibn Abdilla.: Al Qanun fi al T\{ib. Dar al Kotob al Ilmiy ah, Beirut (1999)

[2] Winkelman, M.: Culture and Health Applying Medical Anthropology. John Wiley and Sons, (2009).

[3] Nagamia, H.: Islamic Medicine History and Current Practice. Journal of the International Society for the History of Islamic Medicine (JISHIM). Vol. 2, pp. 20-21 (2003)

[4] Ibn Manz \{ur, Muhammad ibn Mukram.: Lisa>n al 'Arab. Dar Sadir, Beirut (1980)

[5] Al Dinawari, Muhammad ibn 'Abdullah Ibn Qutayba.: Ta'wil Mukhtalaf al Hadith. Al Maktab al Isla>mi, Beirut (1999).

[6] Safitri, D.: Construction Ghaib Magazine against Ruqyah Syar'iyyah. Asian Journal of Humanities and Social Studies. Vol. 1, No. 3, p. 122 (2013)

[7] Raiya, Abu et. al.: Empirically based psychology of Islam: summary and critique of the literature. Mental Health, Religion \& Culture. Vol. 14, No. 2, pp. 93-115 (2011)

[8] Mohamad, M. A. et. al.: The Ruqyah Syar'iyyah Spiritual Method As An Alternative For Depression Treatment. Life Science Journal. Vol. 14, No. 2, pp. 79 (2017) 
[9] Tahhan, M.: Us\{ul al Takhri>j wa Dirasa>t al Asani>d. Dar al Andalos al Khadra’, Jeddah (2005)

[10] Al Baqi, F. A.: Mifta $>$ h Kunu $>$ z al Sunnah. Idarah Tarjaman al Sunna, Lahore (1978)

[11] Tahhan, M.: Taysi $>$ r Must $\{$ alah al Hadi>th. Dar al Fikr, Beirut (tt)

[12] Ghazaly, Y. A.: Fiqh al Hadith: Genealogi dan Metodologi. Pustaka Tebuireng, Jombang (2017)

[13] Al Zayy an, R. I.: Al Hadith al Mawdlu> 'i> Dira>sa>t Nazriy a>t. Majalla al Jami'ah al Islamiya. Vol. 2, Ed. 10, pp. 207-248 (2002).

[14] Ibn Qay yim.: Al T \{ib al Nabawi>. Dar al Fikr, Beirut (1999)

[15] Wagenfeld-Heintz, E.: One Mind or Two? How Psychiatrists and Psychologists Reconcile Faith and Science. Journal of Religion and Health. Vol. 47, No. 3, pp. 338-353 (2008)

[16] Al Mubarakfuri, Abd al Rahma>n ibn Abd al Rahi>m.: Tuhfat al Ahwadhi. Dar al Kotob al 'Ilmiy y ah, Beirut (tt)

[17] Al Tirmidhi, Muhammad ibn 'Isa.: Sunan al Tirmidhi>. Kitab al Tib, bab al Rukhsah fi al ruqy ah. Dar al Garb al Islami, Beirut (1998)

[18] Al Maliba>ri>, Hamza Abd Allah.: Kayf Nadrus 'Ilma Takhrij al Hadith. Dar al Razi, Amman (1998)

[19] Ibn Anas, Malik.: Al-Muwatta'. Muassasah Zayid ibn Sulthan Alu Nahy an, Abu Dhabi (2004)

[20] Ibn Hanbal, Ahmad.: Musnad Al-Imam Ahmad ibn Hanbal. Muassasah Ar-Risalah, Beirut (1999)

[21] Ibn al Manzur.: Lisan al Arab. Dar Sadir, Beirut (1980)

[22] English Oxford Living Dictionary Online. Accessed in in 30/1/2018 22.48 from https://en.oxforddictionaries.com/definition/magic/

[23] Kruk, R.: Harry Potter in the Gulf: Contemporary Islam and the Occult. British Journal of Middle Eastern Studies. Vol. 32, No. 1, pp. 47-74 (2005)

[24] Al Jaza>iri, Jabir ibn Musa.: Aysar al Tafa>si>r li Kala>m al 'Ali> al Kabi>r. Maktabah al Ulum wa al Hikam, Madinah (2003)

[25] al T\{ant\}awi, Muhammad Sayyid.: Al Tafsi>r al Wasi $>t\}$ li Al Qur'an al Kari $>$ m. Dar al Nahdah, Cairo (1998)

[26] Shihab, M. Q.: Tafsir Al Mishbah: Pesan, Kesan dan Keserasian Al Qur'an. Lentera Hati, Jakarta (2008)

[27] Al Asqalani, Ibn Hajar.: Fath al-Bari ‘ala Sharh Sahih al Bukhari. Dar al Ma'rifah, Beirut (1379 $\mathrm{H})$

[28] Mahfudh, S.: Wajah Baru Fikih Pesantren. LP3ES, Jakarta (2004)

[29] Ibn Khaldun, Abd al Rahman ibn Muhammad ibn Muhammad.: Al Muqaddimah. Maktaba al Hiday ah, Damascus (2004)

[30] Simão. T. P.. Caldeira. S.. and De Carvalho. E. C.: The effect of prayer on patients' health: systematic literature review. Religions. Vol. 7, No. 1, p. 11 (2016)

[31] Bahrien. B.. and Ardiantv. A.: Pengaruh Efektivitas Terabi Self Healing Menggunakan Energi Reiki terhadap Kecemasan Menghadapi Ujian Skripsi. Psympathic: Jurnal Ilmiah Psikologi. Vol. 4, No. 1, pp. 141-148 (2017)

[32] Teut. M.. Besch. F.. Witt. C. M.. and Stöckiot. B.: Perceived outcomes of spiritual healing: Results from a prospective case series. Complementary medicine research. Vol. 26, No. 4, pp. 265-275 (2019)

[33] Oureshi. N. A.. Khalil. A. A.. and Alsanad. S. M.: Spiritual and religious healing practices: some reflections from saudi national center for complementary and alternative medicine, Riy adh. Journal of religion and health. Vol. 59, No. 2, pp. 845-869 (2020)

[34] Sutioningsih. S.. Suniawati. S.. and Hamsanikeda. S.: Pengaruh Terapi Meditasi (Dzikir) terhadap Tingkat Stres pada Lansia. Jurnal Keperawatan Profesional. Vol. 7, No. 1 (2019).

[35] Fadli. F.. Reskv. R.. and Sastria. A.: Pengaruh Terapi Dzikir terhadap Intensitas Nyeri pada Pasien Gastritis. Jurnal Kesehatan. Vol. 10, No. 2, 169-174 (2019) 
[36] Gunawan. A. S.. and Sureskiarti. E.: Analisis Praktik Klinik Keperawatan pada Pasien Chronic Kidney Disease (CKD) dengan Intervensi Inovasi Terapi Meditasi Dzikir dan Mendengarkan Murottal Surat Ar Rahman terhadap Penurunan Tekanan Darah di Ruang Hemodialisa RSUD Abdul Wahab Sjahranie Samarinda Tahun 2017. (2017)

[37] Schneider, K. J., and Leitner, L. M.: Humanistic Psy chotherapy: Ency clopedia of Psy chotherapy. Vol. 1, Michel Hersen and William Sledge (ed.). Elsevier Science, USA (2002)

[38] Subandi.: Latihan Meditasi untuk Psikoterapi. Dalam Psikoterapi: Pendekatan Konvensional dan Kontemporer by Subandi (ed.). Pustaka Pelajar dan Unit Publikasi Fakultas Psikologi UGM, Yogy akarta (2003)

[39] Rakhmat, J.: Psikologi Komunikasi. Remaja Rosdakarya, Bandung (2015)

[40] Guilmartin, N.: Healing Conversations: What to Say, When You Don't Know Ehat to Say. Jossey-Bass, San Fransisco (2002)

[41] Luk. K. H.: Holistic Praver for Healing: Phvsical, Psychological, Spiritual And Social Perspectives. Diss. Anglia Ruskin University, (2019)

[42] Ibnu Qayyim.: Madarijus Salikin: Pendakian Menuju Allah-Penjabaran Konkrit "Iy y akaNa'buduwa Iy y akaNasta'in". Kathur Suhardi (terj.). Pustaka al-Kautsar, Jakarta (2019)

[43] Rajab, K.: Psikoterapi Islam. Amzah, Jakarta (2019)

[44] Keshavarzi, H., \& Haque, A.: Outlining a Psychotherapy Model for Enhancing Muslim Mental Health within an Islamic Context. The International Journal for the Psychology of Religion, Vol. 23, No. 3, pp. 230-249 (2013)

[45] Al Jauziyah In Nashori, F. et al.: Terapi Ruqyah Syar’iyyah meningkatkan kebahagiaan perempuan korbankekerasan dalam rumah tangga. Jurnal Intervensi Psikologi, Vol. 11, No. 2, pp. 111-122 (2019)

[46] Al-Qurthubi dalam Sya'roni and Khotimah, K.: Terapi Ruqyah dalam Pemulihan Kesehatan Mental. Journal of Islamic Guidance and Counseling. Vol. 2, no. 1, p. 82 (2018)

[47] Rafique, R. et al.: Efficacy of Surah al-Rehman in Managing Depression in Muslim Women. Journal Religious Health. Springer Science-Business Media, p. 9 (2017)

[48] Ghiasi, A. and Keramat, A. The Effect of Listening to Holy Quran Recitation on Anxiety: A Systematic Review. Iranian Journal of Nursing and Midwifery Research. Vol. 3, No. 6, p. 411 (2018)

[49] Ria. G.. Mava. A.. and Jamalluddin. S. B.: Murotal Al-Ouran therapy on decreasing labor pain and anxiety in maternity mothers first phase. Enfermería Clínica. Vol, 30, pp. 110-114 (2020)

[50] Arifuddin. Y. W.. and Fahmi. A. Y.: The Effect of Ruavah Svar'ivvah Theranv on Anxietv. Stress and Depression Among Health Science Students. Holistic Nursing and Health Science. Vol. 1, No. 2, pp. 68-76 (2018)

[51] Ali. M. S.. et al.: Anxietv Therapv Bv Practising And Reciting Al-Fatiha Sura: An Alternative Remedv. International Journal of Academic Research in Business and Social Sciences. Vol. 8, No. 7, pp. 921-929 (2018)

[52] Razali. Z. A.. Rahman. N. A. A.. and Husin. S.: Complementing the Treatment of a Maior Depressive Disorder Patient with Ruqy ah Shar 'iyy ah Therapy: A M alay sian Case Study. Journal of Muslim Mental Health. Vol. 12, No. 2 (2018)

[53] Afifuddin. M.M.. and Noorain. O.: The Ruav ah Svar'ivv ah spiritual method as an alternative for depression treatment. Mediterranean Journal of Social Sciences. Vol. 7, No. 4, pp. 406-406 (2016)

[54] Satrianegara. M. F.. Hadiu. V.. Amiruddin. R.. and Idrus. M. F.: The Role of Religious Psvchotherapv with Independent Ruavah in Reducing Depression and Improved Spiritual Quality of Life of Cancer Patients at Hospital of Hasanuddin University Makassar. International Journal of Sciences: Basic and Applied Research (IJSBAR). Vol. 27, No. 1, pp. 1-9 (2016)

[55] Ismail. S.. Husain. R.. Omar. S. H. S.. \& Mohamad. N.: An Application Of Healing Verses (As Syifa Verses) As Therapy Approach To Reduce Stress in Drug Addiction. International Journal of Civil Engineering and Technology (IJCIET). Vol. 9, No. 9, pp. 165-173 (2018) 
[56] Hofie. L.: Ruavah svar'ivvah sebagai terapi alternatif penderita gangguan psikosomatik: studi kasus pasien Penderita Psikosomatik di Al-Baharun Ketapang Sampang. Diss. UIN Sunan Ampel, Surabay a (2019).

[57] Husin. E. R.. Junoh. H.. Nizar. T. J.. Jasmi. K. A.. Marni. N.. and Jidi. K. M.: Tingkah Laku Pesakit Histeria Menurut Perspektif Perubatan Ruavah Shar 'Ivvah (Behavior of Hvsterical Patient Based on Ruqyah Shar 'iy y ah Medication Perspective). Jurnal Hadhari: An International Journal. Vol. 10, No. 1, pp. 63-76 (2018)

[58] Ikhsan. D.. Fahmi. M. I.. and Mafan. A.: Model Psikoterapi Zikir dalam Meningkatkan Kesehatan Mental. Academica: Journal of Multidisciplinary Studies. Vol. 1, No. 2, pp. 273-283 (2017)

[59] Koenig. H. G.. and Al Shohaib. S. S.: Religiosity and mental health in Islam. Islamophobia and psychiatry. Cham, Springer, pp. 55-65 (2019)

[60] Taniung. J. G.: Kondisi Psikologis Pasien Quranic Healing International (QHI) Pasca Ruqyah. Diss. IAIN Bengkulu, Bengkulu (2019)

[61] Javanti. A. M.. Nashori. F.. and Rumiani. R.: Terapi Rugvah Svar'ivvah Meningkatkan Kebahagiaan Perempuan Korban Kekerasan dalam Rumah Tangga. JIP: Jurnal Intervensi Psikologi. Vol. 11, No. 2, 111-122 (2019)

[62] Alshammary, S., Duraisamy, A. B., Al-Odeh, F. et. al.: The Satisfaction of Ruqyah on Cancer Patients. International Journal of Research Studies in Medical and Health Sciences. Vol. 3, No. 8 , pp. 1-5 (2018)

[63] Rohmansyah, R., Iriansyah, M. S., Ilhami, F., and Utomo, G. A. W.: Hadis-Hadis Ruqyah dan Pengaruhny a Terhadap Kesehatan Mental. Jurnal Ilmiah Islam Futura. Vol. 18, No. 1, pp. 75-104 (2018) 